\title{
Effect of oyster mushroom wastes on performance, immune responses and intestinal morphology of broiler chickens
}

\author{
Shila Hasanian Fard • Majid Toghyani • \\ Sayed Ali Tabeidian
}

Received: 24 April 2014/ Accepted: 9 September 2014/Published online: 30 September 2014

(C) The Author(s) 2014. This article is published with open access at Springerlink.com

\begin{abstract}
Background Mushroom wastes are widely left from mushroom production industries and have been supposed to possess prebiotic, antimicrobial, antifungal and antioxidant properties. Due to difficulties with using antibiotic growth promoters in poultry diet, mushroom wastes seem to be a proper substitute for them. Therefore, present experiment was carried out to investigate the effect of oyster mushroom wastes on performance, immune responses and intestinal morphology of broiler chickens. To conduct the trial, total of 210-day-old broiler chickens (Ross 308) were assigned to 3 dietary treatments and 5 replicates of 14 mixed birds. Subsequently, performance, immunity and intestinal morphology parameters were evaluated throughout the experiment. Results $1 \%$ mushroom wastes inclusion not significantly increased body weight (BW), weight gain (WG) and feed intake (FI) of chickens $(P>0.05)$, while using $2 \%$ of these wastes deteriorated BW and feed conversion ratio (FCR) $(P<0.05)$. At 28 days of age, villus height and crypt depth of jejunum were significantly increased using both levels of mushroom wastes, however, these indices impaired in ileum with the same mushroom levels $(P<0.05)$. With the exception of antibody titer against Newcastle disease virus which was compromised using $2 \%$, other antibody-related parameters were not affected by supplementing $1 \%$ mushroom wastes $(P>0.05)$. The
\end{abstract}

\author{
S. H. Fard · M. Toghyani $(\bowtie) \cdot S$. A. Tabeidian \\ Department of Animal Science, Khorasgan (Isfahan) Branch, \\ Islamic Azad University, Isfahan, Iran \\ e-mail: toghiani@hotmail.com \\ S. H. Fard \\ e-mail: Shantia.hasani@yahoo.com \\ S. A. Tabeidian \\ e-mail: Tabeidian@yahoo.com
}

ratio of heterophil to lymphocyte also decreased by the waste inclusion $(P<0.05)$.

Conclusion Mushroom wastes in $1 \%$ inclusion are able to improve some parameters of performance and immunity of broiler chicks. Nonetheless, supplementation in $2 \%$ might compromise the mentioned indices.

Keywords Broiler chickens - Mushroom wastes · Performance · Immunity · Intestinal morphology

\section{Introduction}

Antimicrobial growth promoters have been largely consumed in animal production and have supported the considerable achievements of the poultry industry. However, emergence of resistant bacteria drove the European Union to ban the antibiotics usage. This situation motivated researchers to find new alternatives for antibiotic growth promoters. Plant origin feed additives with beneficial therapeutic effects helps eliminating antibiotics from poultries diet. To do so, using food industry wastes might be able to meet this target and also contribute to remove the nonfunctional residues from the environment. Mushrooms contain of antioxidants, phenolic compounds, tocopherols, carotenoids, and antibacterial compounds (Zhou et al. 2010; Hernandez et al. 2004). Additionally, mushrooms have been reported to have immunoenhancing and stress-reducing properties (Dalloul and Lillehoj 2006; Borchers et al. 2008). Oyster mushrooms (Pleurotus ostreatus) are one of the commonly cultivated mushroom species which have antiviral and anticancer properties (Bobek and Galbavy 2001; Jedinak and Sliva 2008). Damaged and malformed mushrooms as well as basis or strips of them are different forms of wastes left during mushroom production. These wastes are 
Table 1 Ingredients and nutrient specifications of experimental diets applied in starter, grower, and finisher periods

\begin{tabular}{|c|c|c|c|c|c|c|c|c|c|}
\hline & \multicolumn{3}{|c|}{ Starter (1-14 days) } & \multicolumn{3}{|c|}{ Grower (14-28 days) } & \multicolumn{3}{|c|}{ Finisher (28-42 days) } \\
\hline & ${ }^{\mathrm{a}} \mathrm{CON}$ & M1\% & M2 \% & $\mathrm{CON}$ & M1\% & M2\% & $\mathrm{CON}$ & M1 \% & $\mathrm{M} 2 \%$ \\
\hline Corn $(8 \% \mathrm{CP})$ & 56.3 & 54.96 & 53.61 & 56.59 & 54.91 & 53.29 & 58.24 & 56.89 & 55.49 \\
\hline Soybean meal (44 \% CP) & 38.1 & 38.1 & 38.1 & 36.7 & 36.8 & 36.9 & 35 & 35 & 35.1 \\
\hline Mushroom wastes $(9.9 \% \mathrm{CP})$ & - & 1 & 2 & - & 1 & 2 & - & 1 & 2 \\
\hline Soybean oil & 1.2 & 1.54 & 1.89 & 3 & 3.58 & 4.1 & 3.35 & 3.7 & 4 \\
\hline Dicalcium phosphate & 1.91 & 1.91 & 1.91 & 1.68 & 1.68 & 1.68 & 1.53 & 1.53 & 1.53 \\
\hline Calcium carbonate & 1.13 & 1.13 & 1.13 & 0.93 & 0.93 & 0.93 & 0.91 & 0.91 & 0.91 \\
\hline DL-Methionine & 0.33 & 0.33 & 0.33 & 0.24 & 0.24 & 0.24 & 0.17 & 0.17 & 0.17 \\
\hline L-lysine. $\mathrm{HCl}$ & 0.23 & 0.23 & 0.23 & 0.06 & 0.06 & 0.06 & 0 & 0 & 0 \\
\hline Vitamin premix $^{\mathrm{b}}$ & 0.25 & 0.25 & 0.25 & 0.25 & 0.25 & 0.25 & 0.25 & 0.25 & 0.25 \\
\hline Mineral premix ${ }^{c}$ & 0.25 & 0.25 & 0.25 & 0.25 & 0.25 & 0.25 & 0.25 & 0.25 & 0.25 \\
\hline Salt & 0.3 & 0.3 & 0.3 & 0.3 & 0.3 & 0.3 & 0.3 & 0.3 & 0.3 \\
\hline \multicolumn{10}{|l|}{ Calculated composition } \\
\hline $\mathrm{ME}(\mathrm{kcal} / \mathrm{kg})$ & 2,850 & 2,850 & 2,850 & 3,000 & 3,000 & 3,000 & 3,050 & 3,050 & 3,050 \\
\hline Crude protein $(\%)$ & 21.27 & 21.27 & 21.27 & 20.7 & 20.7 & 20.7 & 20 & 20 & 20 \\
\hline Crude fiber (\%) & 3.905 & 4.205 & 4.504 & 3.813 & 4.113 & 4.413 & 3.731 & 4.030 & 4.335 \\
\hline Lysine (\%) & 1.35 & 1.35 & 1.35 & 1.18 & 1.18 & 1.18 & 1.09 & 1.09 & 1.09 \\
\hline Methionine + cysteine $(\%)$ & 1 & 1 & 1 & 0.9 & 0.9 & 0.9 & 0.82 & 0.82 & 0.82 \\
\hline Tryptophan (\%) & 0.314 & 0.314 & 0.314 & 0.304 & 0.304 & 0.298 & 0.293 & 0.293 & 0.292 \\
\hline Calcium $(\%)$ & 1 & 1 & 1 & 0.86 & 0.86 & 0.86 & 0.80 & 0.80 & 0.80 \\
\hline Available phosphorous (\%) & 0.47 & 0.47 & 0.47 & 0.43 & 0.43 & 0.43 & 0.40 & 0.40 & 0.40 \\
\hline $\mathrm{Na}(\%)$ & 0.131 & 0.130 & 0.130 & 0.131 & 0.130 & 0.130 & 0.131 & 0.131 & 0.131 \\
\hline
\end{tabular}

${ }^{a} \mathrm{CON}, \mathrm{M} 1 \%$, and M2 \% represent diet supplemented with dried Pleurotus ostreatus mushroom at the level of 1 and $2 \%$ of feed, respectively

b Vitamin premix per kg of diet: vitamin A (retinol), $2.7 \mathrm{mg}$; vitamin D3 (Cholecalciferol), $0.05 \mathrm{mg}$; vitamin E (tocopheryl acetate), $18 \mathrm{mg}$; vitamin k3, $2 \mathrm{mg}$; thiamine $1.8 \mathrm{mg}$; riboflavin, $6.6 \mathrm{mg}$; pantothenic acid, $10 \mathrm{mg}$ pyridoxine, $3 \mathrm{mg}$; cyanocobalamin, $0.015 \mathrm{mg}$; niacin, $30 \mathrm{mg}$; biotin, $0.1 \mathrm{mg}$; folic acid, $1 \mathrm{mg}$; choline chloride $250 \mathrm{mg}$; $100 \mathrm{mg}$ ethoxyquin as antioxidant

${ }^{c}$ Mineral premix per kg of diet: Fe (FeSO4.7H2O, $20.09 \% \mathrm{Fe}$ ), $50 \mathrm{mg}$; Mn (MnSO4.H2O, $\left.32.49 \% \mathrm{Mn}\right), 100 \mathrm{mg} ; \mathrm{Zn}(\mathrm{ZnO}, 80.35 \% \mathrm{Zn})$, $100 \mathrm{mg}$; $\mathrm{Cu}$ (CuSO4.5H2O), $10 \mathrm{mg}$; I (KI, $58 \%$ I), $1 \mathrm{mg}$; Se (NaSeO3, $45.56 \% \mathrm{Se}) 0.2 \mathrm{mg}$

usually collected daily and transferred out of the production site. It has been reported that combination of mushroom extract and Chinese herbals may act as an antibiotic growth promoter in broilers diet (Guo et al. 2004). Moreover, the polysaccharides from Lentinula edodes stipe, Pleurotus eryngii base, and Flammulina velutipes base increased the survival rate of Lactobacillus acidophilus, Lactobacillus casei, and Bifidobacterium longum subsp. longum during cold storage (Chou et al. 2013). In another study, Giannenas et al. (2010) observed the favorable effect of Agaricus bisporus on antioxidant protective activity of broiler chickens. Despite mentioned studies and some other conducted experiments in this field (Hernandez et al. 2004; Kavyani et al. 2012; Lee et al. 2012; Toghyani et al. 2012), data on mushroom wastes are scarce. Therefore, the aim of the present trial was to investigate the effect of different levels of oyster mushroom wastes on performance, immune responses and intestinal morphology of broiler chickens.

\section{Methods}

Birds and management

Two hundred and ten-day-old broiler chickens (Ross 308) were purchased from a local hatchery, weighted on arrival and randomly allocated to 3 treatments and 5 replicates of 14 chickens each in completely randomized design. The effect of mushroom waste was evaluated through the 0,1 and $2 \%$ of oyster mushroom addition to the basal diet. Chickens were fed by dietary treatments during the starter (1-14 days), growing (14-28 days) and finishing (28-42) phases. Feed and water were provided ad libitum throughout the trial. The ambient temperature was gradually decreased from 33 to $25^{\circ} \mathrm{C}$ on day 21 and was then kept constant. Ingredients and nutrient specifications of experimental diets are shown in Table 1. 
Table 2 Composition of the oyster mushroom waste

\begin{tabular}{ll}
\hline Mushroom composition & \\
\hline Crude protein (\%) & 9.9 \\
Crude fiber (\%) & 32.9 \\
Crude fat (\%) & 0.48 \\
Ash (\%) & 3.8 \\
Calcium (\%) & 0.06 \\
Total phosphorous (\%) & 0.26 \\
Moisture (\%) & 5.1 \\
Metabolizable energy & 1,270 \\
$\quad$ kcal/kg) & \\
\hline
\end{tabular}

Mushroom waste preparation and analysis

Prior to trial initiation, fresh oyster mushroom wastes were provided from a local producer, dried in the oven $\left(55^{\circ} \mathrm{C}\right)$, ground through a 5-mm sieve before hand mixing and incorporation into diet. For chemical analysis, mushroom wastes freeze-dried via a 1-mm sieve before analysis for protein, fat, fiber and ash according to the procedures described in AOAC International (1995). Kjeldahl method was used to determine total protein content, crude fat content was extracted from the samples with petroleum ether in a Soxhlet apparatus, crude fiber content was analyzed in a Dosi Fiber apparatus and ash was measured by incinerating dried samples at $600{ }^{\circ} \mathrm{C}$ for about $6 \mathrm{~h}$ in a furnace and moisture by oven drying. Phosphorus and calcium contents of the wastes were analyzed by inductively coupled plasma-optical emission spectroscopy following an aqua regia digestion step. Table 2 shows the result of analysis.

\section{Performance parameters}

BW and WG were determined during different phases of the experiment. At the same time, FI and WG of starter, growing and finishing phases were determined and FCR also (FI/WG) was calculated.

\section{Small intestinal morphology}

At day 28 of age, two male birds of each pen were slaughtered and intestinal samples were taken immediately from the jejunum; midway between the point of entry of the bile ducts and Meckel's diverticulum, ileum; $10 \mathrm{~cm}$ proximal to the ileocecal junction were taken to evaluate the villus height, crypt depth and villus height: crypt depth ratio. Segments which were $1.5 \mathrm{~cm}$ in length were flushed with saline and fixed in $100 \mathrm{~g}^{-1}$ buffered formalin $(\mathrm{pH}$ 7.0). The fixed intestinal samples embedded in paraffin then sectioned $(5 \mu \mathrm{m})$ and stained with hematoxylin-eosin and examined by light microscope. Villus height $(\mu \mathrm{m})$ was measured from the tip of the villus to the villus-crypt junction and crypt depth was measured from the base upward to the region of transition between the crypt and villus.

Humoral immunity and heterophil to lymphocyte ratio

At 9 days of age, Newcastle and influenza antigens were injected to chickens with dual vaccine of Newcastleinfluenza. Two male chickens per pen were selected randomly for intraperitoneal injection with a $1.0 \mathrm{ml}$ of sheep red blood cells (SRBC) suspension diluted with phosphate buffer saline (pbs) on day 23. Six days later, the same wing-banded birds were bled to determine antibody titer against SRBC and also against influenza and Newcastle. Subsequently, antibody titer against SRBC was measured by hemagglutination assay method and also antibody titer against influenza and Newcastle separately was measured by hemagglutination inhibition method. Hemagglutination inhibition antibodies were then converted to $\log 2$. Antibody titers against SRBC were measured by the microtitre procedure described by Wegmann and Smithies (1966). At the end of the experiment, birds were slaughtered after taking blood samples then spleen and bursa of fabricius weighed to determine the immune system development.

Heterophil to lymphocyte ratio was obtained by blood sampling on day 29. In this process, syringes containing heparin were used to avoid blood clot formation. Blood smears were stained by May-Greenwald-Giemsa stain (Lucas and Jamroz 1961). A hundred leukocytes per samples were counted by heterophil to lymphocyte separation under an optical microscope and heterophil to lymphocyte $(\mathrm{H} / \mathrm{L})$ ratio was calculated and recorded (Gross and Siegel 1983).

Lymphoid organs relative weight

At 28 days of age, two male birds of each pen were randomly selected, weighted and slaughtered. Then spleen and bursa of fabricius were excised, weighed and calculated as a percentage of live BW.

Statistical analysis

Data were subjected to the analysis of variance appropriate for a completely randomized design by SAS (2008). The least significant different (LSD) test was applied to separate different means. Statements of statistical significance were based on a probability of $P<0.05$. 


\section{Results and discussion}

Performance parameters

According to Table 3, although $1 \%$ mushroom wastes inclusion had no significant effect on the whole period BW and WG of broilers, marginally increased these indices $(P>0.05)$. On the contrary, using $2 \%$ of mushroom wastes decreased BW $(P<0.05)$. Supplementation of $1 \%$ mushroom wastes led to the significant increase of the FI $(P<0.05)$, while no impact of $2 \%$ mushroom wastes observed. Increased FI of chickens using $1 \%$ mushroom wastes might be the reason of insignificant increase in BW of broilers. In addition, the slight improvement of BW through supplementation of $1 \%$ mushroom wastes could be explained by the oligosaccharide existence in the mushrooms cell wall and its growth promoter role as a prebiotic which may have positively affected the microflora balance of the intestinal tract (Chou et al. 2013). Additionally, the decreased BW of chickens fed $2 \%$ mushroom wastes in whole period might have been partially due to the high fiber contents and subsequently reduced nutrient utilization of the chickens. This BW decrease finally led to the higher FCR in this group $(P<0.05)$. In contrast to this trial, Willis et al. (2013) exhibit the marked increase in BW of the chickens using $5 \%$ oyster mushroom at 49 days of the age. On the other hand, Toghyani et al. (2012) reported the lower BW of chickens fed $2 \%$ mushroom compared to the $1 \%$ inclusion which is in agreement with this experiment.

Intestinal morphology

Intestinal morphology of the control and supplemented chickens is summarized in Table 4. Villus height and crypt depth of the jejunum were significantly increased using 1 and $2 \%$ of mushroom wastes $(P<0.05)$. Inversely, these indices were decreased in ileum by both levels of mushroom waste supplementation $(P<0.05)$. Despite the changes in the villus height and crypt depth of jejunum, no considerable impact of mushroom wastes on villus height to crypt depth ratio was observed, while this ratio increased in ileum $(P<0.05)$. The higher villus height and lower crypt depth are associated with the gut health and higher intestinal absorptive capacity. The structural alternations in the small intestine of the birds in this study might be related to the high content of fiber in mushroom wastes, however, eventually did not affect the villus height to crypt depth ratio. Giannenas et al. (2011) reported the increased villus height of the birds in duodenum, jejunum and ileum fed 1 and $2 \%$ mushrooms, which is similar with the obtained results of the current trial in jejunum.
Table 3 Effect of different levels of oyster mushroom waste on whole period performance ( $0-42$ days) of broiler chickens

\begin{tabular}{|c|c|c|c|c|c|}
\hline \multirow[t]{3}{*}{ Performance } & \multicolumn{4}{|c|}{ Treatments } & \multirow[t]{3}{*}{$P$ value } \\
\hline & \multirow[t]{2}{*}{ Control } & \multicolumn{2}{|c|}{ Mushroom waste } & \multirow[t]{2}{*}{ SEM } & \\
\hline & & $1 \%$ & $2 \%$ & & \\
\hline Body weight (g) & $2,339^{\mathrm{ab}}$ & $2,411.4^{\mathrm{a}}$ & $2,045.6^{\mathrm{c}}$ & 49.21 & 0.03 \\
\hline $\begin{array}{l}\text { Weight gain } \\
\text { (g/day) }\end{array}$ & $54.6^{\mathrm{ab}}$ & $56.0^{\mathrm{a}}$ & $51.1^{\mathrm{b}}$ & 1.23 & 0.045 \\
\hline $\begin{array}{l}\text { Feed intake } \\
\text { (g/day) }\end{array}$ & $95.1^{\mathrm{b}}$ & $97.7^{\mathrm{a}}$ & $96.5^{\mathrm{ab}}$ & 1.10 & 0.042 \\
\hline FCR (g:g) & $1.74^{\mathrm{b}}$ & $1.74^{\mathrm{b}}$ & $1.88^{\mathrm{a}}$ & 0.028 & 0.011 \\
\hline
\end{tabular}

$F C R$, feed conversion ratio

a,b,c Values in the same row not sharing a common superscript differ significantly $(P<0.05)$

Table 4 Effect of different levels of oyster mushroom waste on the intestinal morphology of broiler chickens

\begin{tabular}{llllll}
\hline Parameters $(\mu \mathrm{m})$ & \multicolumn{2}{l}{ Treatments } & $P$ value \\
\cline { 2 - 4 } & Control & \multicolumn{2}{l}{ Mushroom waste } & SEM & \\
\cline { 3 - 4 } & & $1 \%$ & $2 \%$ & & \\
\cline { 3 - 4 } Jejunum & & & & & \\
Villi height & $1,010^{\mathrm{b}}$ & $1,239^{\mathrm{a}}$ & $1,223^{\mathrm{a}}$ & 47.50 & 0.012 \\
Crypt depth & $183^{\mathrm{b}}$ & $187^{\mathrm{b}}$ & $209^{\mathrm{a}}$ & 10.97 & 0.025 \\
V/C & 5.51 & 6.62 & 5.85 & 0.60 & 0.091 \\
Ileum & & & & & \\
Villi height & $635^{\mathrm{a}}$ & $508^{\mathrm{b}}$ & $515^{\mathrm{b}}$ & 16.78 & 0.043 \\
Crypt depth & $180^{\mathrm{a}}$ & $163^{\mathrm{b}}$ & $153^{\mathrm{b}}$ & 4.31 & 0.047 \\
V/C & $3.53^{\mathrm{a}}$ & $3.12^{\mathrm{b}}$ & $3.37^{\mathrm{b}}$ & 0.13 & 0.033 \\
\hline a,b Values in the same row not sharing a common superscript differ \\
significantly $(P<0.05)$
\end{tabular}

Humoral immunity and heterophil to lymphocyte ratio

Regarding Table 5, chickens fed diets supplemented with $1 \%$ mushroom wastes showed the marginal enhancement of antibody titers against influenza disease virus and SRBC $(P>0.05)$. Mushrooms encompass of immune-enhancing substances such as polysaccharides, glycosides, alkaloids, volatile oils, and organic acids (Yang and Feng 1998; Willis et al. 2007). Moreover, Selenium is an abundant trace element in mushrooms (Vetter and Lelley 2004), which promotes the antioxidant potential of them and consequently enhances the immunity of consumer animals. Furthermore, mushrooms and their extracted polysaccharides also have been exhibited to have protective effects against $E$. Tenella infection (Guo et al. 2004). Interestingly, despite all the beneficial properties of mushroom, chickens fed $2 \%$ mushroom extract in this trial significantly decreased antibody titer against Newcastle disease virus 
Table 5 Effect of different levels of oyster mushroom waste on humoral immunity and heterophil to lymphocyte ratio

\begin{tabular}{lllllll}
\hline Variable & \multicolumn{2}{l}{ Treatments } & $P$ value \\
\cline { 2 - 4 } & Control & \multicolumn{2}{l}{ Mushroom waste } & SEM & \\
\cline { 3 - 5 } & & $1 \%$ & $2 \%$ & & \\
\hline Influenza $(\log 2)$ & 6.20 & 6.60 & 6.50 & 0.432 & 0.718 \\
New castle $(\log 2)$ & $6.40^{\mathrm{a}}$ & $6^{\mathrm{a}}$ & $4.90^{\mathrm{b}}$ & 0.452 & 0.047 \\
SRBC $(\log 2)$ & 7.70 & 8.40 & 7.60 & 0.474 & 0.135 \\
H/L & $0.617^{\mathrm{a}}$ & $0.587^{\text {ab }}$ & $0.473^{\mathrm{b}}$ & 0.06 & 0.019 \\
\hline
\end{tabular}

$S R B C$ sheep red blood cells, $H / L$ heterophil to lymphocyte ratio

a,b,c Values in the same row not sharing a common superscript differ significantly $(P<0.05)$

$(P<0.05)$. Although the humoral immunity against Newcastle has been expected to be elevated, more research is warranted. The slight increase in antibody titer against influenza virus was comparable to the values obtained by Toghyani et al. (2012). Conversely, they reported the increased produced antibody titer against Newcastle virus. Enhanced antibody titer against SRBC using $3 \%$ mushrooms also have been suggested by Kavyani et al. (2012).

As Table 5 shows, heterophil to lymphocyte ratio decreased in both levels of supplemented mushroom wastes particularly in $2 \%$ of inclusion $(P<0.05)$. The heterophil to lymphocyte ratio is the indicator of the physiological stress as the numbers of heterophils increase during moderately stressful conditions (Maxwell and Robertson 1995). Due to the fact that there is no disease challenge in this trial, the ratio of heterophil to lymphocyte has not been expected to increase. Therefore, decreased ratio might show that mushroom wastes did not impose any stress. Same findings were reported by Toghyani et al. (2012) who showed the marginal decrease of this ratio. In contrast, findings in the work of Willis et al. (2013) illustrated the increased heterophil to lymphocyte ratio of chickens fed by Shiitake (Lentinus edodes) and Reishi (Ganoderma lucidum) mushrooms.

\section{Lymphoid organs' relative weight}

Effects of control group and mushroom supplementation on lymphoid organs are shown in Table 6. None of the lymphoid organs were affected by mushroom wastes inclusion in either 28 or 42 days of age. The greater bursa weight commonly reflects better health status and also the better anatomical response to immune system changes due to stress (Willis et al. 2013). The lack of the mushroom influence on lymphoid organs has been previously indicated by other researchers (Toghyani et al. 2012; Kavyani et al. 2012).
Table 6 Effect of different levels of oyster mushroom waste on lymphoid organs relative weight

\begin{tabular}{|c|c|c|c|c|c|}
\hline \multirow{3}{*}{$\begin{array}{l}\text { Lymphoid organs (\% } \\
\text { BW) }\end{array}$} & \multicolumn{4}{|c|}{ Treatments } & \multirow[t]{3}{*}{$P$ value } \\
\hline & \multirow[t]{2}{*}{ Control } & \multicolumn{2}{|c|}{$\begin{array}{l}\text { Mushroom } \\
\text { waste }\end{array}$} & \multirow[t]{2}{*}{ SEM } & \\
\hline & & $1 \%$ & $2 \%$ & & \\
\hline \multicolumn{6}{|l|}{ Spleen } \\
\hline Day 28 & 0.138 & 0.110 & 0.115 & 0.014 & 0.112 \\
\hline Day 42 & 0.152 & 0.151 & 0.143 & 0.014 & 0.792 \\
\hline \multicolumn{6}{|l|}{ Bursa of fabricius } \\
\hline Day 28 & 0.093 & 0.152 & 0.100 & 0.025 & 0.268 \\
\hline Day 42 & 0.066 & 0.068 & 0.089 & 0.010 & 0.094 \\
\hline
\end{tabular}

a,b,c Values in the same row not sharing a common superscript differ significantly $(P<0.05)$

\section{Conclusion}

It could be concluded that supplementing diets with $1 \%$ mushroom wastes enhances some immunity parameters of chickens to some extent, however, the effect on Newcastle disease virus was compromised and requires more investigation. Gut morphology was affected by mushroom wastes particularly in ileum and jejunum. Feeding chickens with $2 \%$ mushroom wastes decreased the production performance of broilers so consumers should care about the applied levels in the diet.

Authors' contributions All authors have made adequate effort on all parts of the work necessary for the development of this manuscript according to their expertise. All authors read and approved the final manuscript.

Conflict of interests The authors declare that there is no conflict of interest.

Open Access This article is distributed under the terms of the Creative Commons Attribution License which permits any use, distribution, and reproduction in any medium, provided the original author(s) and the source are credited.

\section{References}

AOAC International (1995) Official Methods of Analysis of AOAC International, sixteenth edn. AOAC Int, Arlington

Bobek P, Galbavy S (2001) Effect of pleuran (beta-glucan from Pleurotus ostreatus) on the antioxidant status of the organism and on dimethylhydrazine-induced precancerous lesions in rat colon. Br J Biomed Sci 58:164-168

Borchers AT, Krishnamurthy A, Keen CL, Meyers FJ, Gershwin ME (2008) The immunobiology of mushrooms. Exp Biol Med 233(3):259-276

Chou WT, Sheih C, Fang TJ (2013) The applications of polysaccharides from various mushroom wastes as prebiotics in different systems. J Food Sci. doi:10.1111/1750-3841.12160 
Dalloul RA, Lillehoj HA (2006) Poultry coccidiosis: recent advancements in control measures and vaccine development. Expert Rev Vaccines 5:143-163

Giannenas I, Pappas IS, Mavridis S, Kontopidis G, Skoufos J, Kyriazakis I (2010) Performance and antioxidant status of broiler chickens supplemented with dried mushroom (Agaricus bisporus) in their diet. Poult Sci 89:303-311

Giannenas I, Tsalie E, Chronis EF, Mavridis S, Tontis D, Kyriazakis I (2011) Consumption of Agaricus bisporus mushroom affects the performance, Intestinal microbiota composition and morphology and antioxidant status of turkey poults. Anim Feed Sci Technol 165:218-229

Gross WB, Siegel PS (1983) Evaluation of heterophil to lymphocyte ratio as a measure of stress in chickens. Avian Dis 27:972-979

Guo FC, Kwakkel RP, Williams BA, Parmentier HK, Li WK, Yang ZQ, Verstegen MWA (2004) Effect of mushroom and herb polysaccharides on cellular and humoral immune responses of Eimeria tenella-infected chickens. Poult Sci 83:1124-1132

Hernandez F, Madrid J, Garcia V, Orengo J, Megias MD (2004) Influence of two plant extracts on broilers performance, digestibility, and digestive organ size. Poult Sci 83:169-174

Jedinak A, Sliva D (2008) Pleurotus ostreatus inhibits proliferation of human breast and colon cancer cells through p53-dependent as well as p53-independent pathway. Int J Oncol 33:1307-1313

Kavyani A, Zare Shahne A, PorReza J, Jalil Haji-abadi SMA, Landy $\mathrm{N}$ (2012) Evaluation of dried powder of mushroom (Agaricus bisporus) as an antibiotic growth promoter substitution on performance, carcass traits and humoral immune responses in broiler chickens. J Med Plant Res 6(1):94-100

Lee TT, Ciou JY, Chiang CJ, Chao YP, Yu B (2012) Effect of Pleurotus eryngii stalk residue on the oxidative status and meat quality of broiler. J Agric Food Chem 60:11157-11163
Lucas AM, Jamroz C (1961) Atlas of Avian Hematology. Agriculture Monograph 25. USDA, Washington, DC

Maxwell MH, Robertson GW (1995) The avian basophilic leukocyte: a review. World Poult Sci J 51(3):307-325

SAS Institute (2008) SAS User's Guide Version 9.02 Review Edition. SAS Institute Inc, Cary NC, p 176

Toghyani M, Tohidi M, Gheisari A, Tabeidian A, Toghyani M (2012) Evaluation of oyster mushroom as a biological growth promoter on performance, humoral immunity and blood characteristics of broiler chicks. J Poult Sci 49:183-190

Vetter J, Lelley J (2004) Selenium level of the cultivated mushroom Agaricus bisporus. Acta Aliment 33:297-301

Wegmann TG, Smithies O (1966) A simple hemagglutination system requiring small amounts of red cells and antibodies. Transfusion 6:67-73

Willis WL, Isikhuemhen OS, Ibrahim SA (2007) Performance assessment of broiler chickens given mushroom extract alone or in combination with probiotics. Poult Sci 86:1856-1860

Willis WL, Wall DC, Isikhuemhen OS, Jackson JN, Ibrahim SA, Hurley SL, Anike F (2013) Effect of level and type of mushroom on performance, blood parameters and natural coccidiosis infection in floor-reared broilers. Open Mycol J 7:1-6

Yang Y, Feng WS (1998) Brochures of isolation and extraction of chemical components from herbs (in Chinese). Chinese Herb Medicine Press, Beijing

Zhou X, Zhu H, Liu L, Lin J, Tang K (2010) A review: recent advances and future prospects of taxol-producing endophytic fungi. Appl Microbiol Biotechnol 86:1707-1717 